\title{
The Diagnostic and Prognostic Value of Serum Procalcitonin among Ventilator Associated Pneumonia Patients*
}

\author{
Ashraf Abd El Halim ${ }^{1}$, Adel Attia ${ }^{1 \#}$, Taysser Zytoun², Hosam Eldeen Salah ${ }^{3}$ \\ ${ }^{1}$ Chest Department, Faculty of Medicine, Zagazig University, Zagazig, Egypt \\ ${ }^{2}$ Critical Care Department, Faculty of Medicine, Alexandria University, Alexandria, Egypt \\ ${ }^{3}$ Clinical Pathology Department, Faculty of Medicine, Zagazig University, Zagazig, Egypt \\ Email: "adelattia68@yahoo.com
}

Received April 2, 2013; revised May 3, 2013; accepted May 10, 2013

Copyright (C) 2013 Ashraf Abd El Halim et al. This is an open access article distributed under the Creative Commons Attribution License, which permits unrestricted use, distribution, and reproduction in any medium, provided the original work is properly cited.

\begin{abstract}
Ventilator-associated pneumonia (VAP) is a complication in as many as $28 \%$ of patients who receive mechanical ventilation. Studies have consistently shown that a delay in diagnosis and treatment increases the mortality risk. The aim of this work was to clarify the role of the serum procalcitonin (PCT) in the diagnosis and the prognosis of ventilator associated pneumonia. Methods: Forty two VAP patients, 20 non VAP-ICU (on mechanical ventilation) admitted patients and 20 healthy control subjects of similar age and sex were included in the study. PCT levels in serum samples were measured in all subjects. Results: There was a highly statistically significant difference $(p$ value $<0.001)$ between VAP patients on one side and non VAP-ICU patients and healthy control subjects on the other side regarding the mean values of PCT. Also, the mean values of PCT were statistically significantly higher $(p<0.001)$ among died VAP group than the survivor VAP group. There was a statistically positive correlation $(p<0.01)$ between mortality prediction scores (APACHE II $(\mathrm{R}=0.449)$, CRIP $(\mathrm{R}=0.403)$ and SOFA $(\mathrm{R}=0.437))$ and initial PCT serum levels. Conclusions: This study found that the increased PCT serum level is an important diagnostic tool for VAP and the PCT serum levels can predict the outcome of VAP patients. We recommend other larger studies to augment our findings.
\end{abstract}

Keywords: Ventilator-Associated Pneumonia (VAP); Procalcitonin (PCT); Acute Physiology and Chronic Health Evaluation II (APACHE II); The Sequential Organ Failure Assessment Score (SOFA); Clinical Pulmonary Infection Score (CPIS)

\section{Introduction}

Ventilator-associated pneumonia (VAP) is pneumonia that develops 48 hours or longer after mechanical ventilation is given by means of an endotracheal tube or tracheostomy. Ventilator-associated pneumonia (VAP) results from the invasion of the lower respiratory tract and lung parenchyma by microorganisms. Intubation compromises the integrity of the oropharynx and trachea and allows oral and gastric secretions to enter the lower airways [1]. Ventilator associated pneumonia (VAP) is a complication in as many as $28 \%$ of patients who receive mechanical ventilation. The incidence of VAP increases with the duration of mechanical ventilation. Estimated rates are 3\% per day for the first 5 days, $2 \%$ per day for days $6-10$, and $1 \%$ per day after day 10 [2]. The crude

${ }^{*}$ The authors declare no conflict of interest.

${ }^{\#}$ Corresponding author. mortality rate of VAP is $27 \%-76 \%$. Studies have consistently shown that a delay in starting appropriate and adequately dosed antibiotic therapy increases the mortality risk.

One of the causes of the high mortality rate is the diagnosis delay [1].

Unlike community-acquired pneumonia, it may be difficult to determine whether pneumonia has developed in a hospitalized ventilator-dependent patient. Symptoms and signs usually are not conclusive. Although the plain chest roentgenogram remains an important component in the evaluation of hospitalized patients with suspected pneumonia, it is most helpful when it is normal and rules out pneumonia. Microscopy evaluation and culture of tracheal secretions and/or expectorated sputum are also frequently inconclusive for patients clinically suspected of having pneumonia, because the upper respiratory tract 
of most patients in the ICU is colonized with potential pulmonary pathogens, whether or not parenchymal pulmonary infection is present [3]. Procalcitonin (PCT) is a peptide precursor of the hormone calcitonin, the latter being involved with calcium homeostasis. It is composed of 116 amino acids and is produced by parafollicular cells ( $\mathrm{C}$ cells) of the thyroid and by the neuroendocrine cells of the lung and the intestine. The level of procalcitonin raises in a response to a proinflammatory stimulus, especially of bacterial origin [4]. Measurement of procalcitonin can be used as a marker of sepsis caused by bacteria and generally grades well with the degree of sepsis [5]. PCT has the greatest sensitivity (85\%) and specificity $(91 \%)$ for differentiating patients with systemic inflammatory response syndrome (SIRS) from those with sepsis [6].

The aim of the work: was to clarify the role of the serum procalcitonin in the diagnosis and the prognosis of ventilator associated pneumonia.

\section{Subjects and Methods}

This study was conducted at the ICU of King Fahad Specialist Hospital, Dammam, Kingdom of Saudi Arabia. The study was approved by Ethics and Research Committee. All patients or their families and control subjects gave their written informed consent before participating in the study. This study included 3 groups of subjects (Table 1):

Group 1: It included 42 VAP patients that were admitted at the ICU. The mean age was $58.09 \pm 13.07$ years. There were $27(64.28 \%)$ males and $15(35.72 \%)$ females.

Group 2: It included 20 non VAP-ICU admitted patients (on mechanical ventilation). The mean age was $56.90 \pm 10.54$ years. There were $12(60 \%)$ males and 8 (40\%) females.

Group 3: It included 20 healthy control subjects. The mean age was $53.85 \pm 11.26$ years. There were $13(65 \%)$ males and 7 (35\%) females.

The three groups were matched for age and sex ( $p$ value $>0.05$ )

All subjects included in this study were undergone for the following:

1) Complete history taking and thorough physical examination.

2) Chest $x$ ray examination.

3) Complete blood picture $(\mathrm{CBC}), \mathrm{C}$ reactive protein (CRP), liver and kidney functions tests.

4) Arterial blood gases analysis (ABGs).

5) Acute Physiology and Chronic Health Evaluation II (APACHE II) score was calculated for patient groups only.

6) The Sequential Organ Failure Assessment score
Table 1. Some basal characteristic data for the subjects included in this study.

\begin{tabular}{|c|c|c|c|}
\hline & $\begin{array}{l}\text { VAP patients } \\
\quad(\mathrm{No}=42)\end{array}$ & $\begin{array}{c}\text { Non VAP } \\
\text { patients } \\
(\text { No }=20)\end{array}$ & $\begin{array}{l}\text { Healthy } \\
\text { Subjects } \\
(\text { No }=20)\end{array}$ \\
\hline Age $($ Mean \pm SD $)$ & $58.09 \pm 13.07$ & $56.90 \pm 10.54$ & $53.85 \pm 11.26$ \\
\hline Sex (Male/Female) & $27 / 15$ & $12 / 8$ & $13 / 7$ \\
\hline $\mathrm{CRP}(\mathrm{mg} / \mathrm{L})$ & $160.4 \pm 4.7$ & $28.53 \pm 2.6$ & $5.38 \pm 1.1$ \\
\hline $\mathrm{WBC}\left(\times 10^{3} / \mu \mathrm{L}\right)$ & $14.5 \pm 3.53$ & $9.6 \pm 0.45$ & $6.5 \pm 1.04$ \\
\hline APACHE II & $24.11 \pm 4.57$ & $16 \pm 3.25$ & $\mathrm{Na}$ \\
\hline SOFA & $7.88 \pm 2.92$ & $3.56 \pm 2.04$ & $\mathrm{Na}$ \\
\hline \multicolumn{4}{|c|}{ Associated conditions } \\
\hline COPD & 8 & 5 & 0 \\
\hline DM & 10 & 4 & 0 \\
\hline Renal failure & 3 & 2 & 0 \\
\hline Heart diseases & 11 & 5 & 0 \\
\hline Malignancy & 7 & 2 & 0 \\
\hline Neurologic diseases & 3 & 1 & 0 \\
\hline Liver cirrhosis & 3 & 2 & 0 \\
\hline
\end{tabular}

(SOFA) was calculated for patient groups only.

7) The Clinical Pulmonary Infection Score (CPIS) was calculated for patient groups only.

8) Measurement of procalcitonin: this was done in all subjects included in this study. Blood samples were taken and the sera were separated and stored at $-80^{\circ} \mathrm{C}$ for further procalcitonin analysis. Procalcitonin levels were determined with the commercially available automated immunochemistry method (Brahms Kryptor, Brahms Liaison, Berlin, Germany) [7]. For VAP patients; PCT measurement was done on the first day of diagnosis (for comparisons with other subject groups) and then repeated on the $5^{\text {th }}$ day of diagnosis.

Pneumonia was classified as VAP if it occurred after 48 hours of mechanical ventilation and was not incubated before the initiation of the mechanical ventilation. Early-onset VAP was defined as that occurring during the first 4 days on mechanical ventilation, whereas VAP developed thereafter was classified as late-onset [8]. A diagnosis of pneumonia was suspected when a new, persistent infiltrate, consolidation, cavitation or pleural effusion was seen on chest X-rays and at least two of the following were observed: a body temperature below $36^{\circ} \mathrm{C}$ or above $38^{\circ} \mathrm{C}$; a white blood cell count lower than $4000 / \mathrm{mm}^{3}$ or higher than $11,000 / \mathrm{mm}^{3}$; and macroscopically purulent tracheal aspirate. Tracheal aspirate was classified as purulent or non purulent after visual inspection. Tracheal aspirate for quantitative culture had been obtained before antimicrobial treatment was started. Tracheal aspirate cultures yielding $\geq 10^{5} \mathrm{CFU} / \mathrm{ml}$ were considered positive. We calculated the clinical pulmonary infection score (CPIS). Patients were assumed to have VAP when the CPIS was $>6$. Patients received a diagnosis of VAP only after other medical conditions to which the presenting symptoms, signs or radiological findings could be attributed had been ruled out. For all patients in 
whom the clinical suspicion of VAP was confirmed, empirical antimicrobial therapy was started immediately and modified after culture results if needed. Patients were followed until resolution of pneumonia or death [9].

\subsection{Exclusion Criteria}

Any patient has any one of the followings was excluded from this study: 1) Age below 18 years; 2) The development of pneumonia within 48 hours of beginning of mechanical ventilation; 3) Evidence of bacterial infection elsewhere; 4) Immunosuppression; 5) Expected early death.

\subsection{Statistical Analysis}

Statistical analysis was performed with the Statistical Package for the Social Sciences, version 16 for Windows (SPSS Inc., Chicago, IL, USA). Values of $p<0.05$ were considered statistically significant.

\section{Results}

The total duration of mechanical ventilation among patients with VAP was $15.35 \pm 9.21$ days compared with $10.67 \pm 8.52$ days in patients without VAP ( $p$ value $<$ $0.01)$. There were 15 (35.71\%) early onset VAP patients and $27(64.29 \%)$ late onset VAP patients. The causative microbes among VAP patients were shown in Table 2.

There was a highly statistically significant difference ( $p$ value $<0.001$ ) between VAP patients on one side and both non VAP-ICU patients and healthy control subjects on the other side regarding the mean values of PCT (1.54 $\pm 0.50 \mathrm{ng} / \mathrm{ml}$ among VAP patients, $0.06 \pm 0.03 \mathrm{ng} / \mathrm{ml}$ among non VAP patients, and $0.04 \pm 0.02 \mathrm{ng} / \mathrm{ml}$ among healthy control subjects) (Table 3 and Figure 1). No statistically significant difference ( $p$ value $>0.05$ ) in the mean values of PCT was present between non VAP-ICU patients and healthy control subjects $(0.06 \pm 0.03 \mathrm{ng} / \mathrm{ml}$ among non VAP patients and $0.04 \pm 0.02 \mathrm{ng} / \mathrm{ml}$ among healthy control subjects) (Table 3 and Figure 1).

$22(52.38 \%)$ patients out of 42 VAP patients survived while $20(47.62 \%)$ patients died. No patient died in the first 5 days after diagnosis. The mean values of PCT were statistically significantly higher $(p$ value $<0.001$ ) among died VAP group than the survivor VAP group on both first day $(1.92 \pm 0.41 \mathrm{ng} / \mathrm{ml}$ vs $1.19 \pm 0.29 \mathrm{ng} / \mathrm{ml}$ respectively) and $5^{\text {th }}$ day measurements $(4.49 \pm 0.59$ $\mathrm{ng} / \mathrm{ml}$ vs $0.81 \pm 0.21 \mathrm{ng} / \mathrm{ml}$ respectively) (Table 4 and Figure 2). The mean values of PCT increased signifycantly from $(1.92 \pm 0.41$ to $4.49 \pm 0.59)$ among died group while decreased significantly from $(1.19 \pm 0.29$ to $0.81 \pm 0.21)$ among the survivor group on repeated testing on the $5^{\text {th }}$ day in comparison with the first day measurement (Table 4 and Figure 2). There was a high statistically positive correlation ( $p$ value $<0.01$ ) between mor-
Table 2. The microbiological profile among the VAP patients.

\begin{tabular}{cc}
\hline Microbes & No of the VAP patients $(\%)$ \\
\hline Staphylococcus aureus & $7(16.67 \%)$ \\
Pseudomonas aeruginosa & $5(11.91 \%)$ \\
Klebsiella pneumoniae & $4(9.52 \%)$ \\
Haemophilus influenzae & $3(7.14 \%)$ \\
Acinetobacter & $2(4.76 \%)$ \\
Enterobacter & $1(2.38 \%)$ \\
Proteus & $1(2.38 \%)$ \\
Serratia & $1(2.38 \%)$ \\
Mixed & $2(4.76 \%)$ \\
Unidentified & $16(38.10 \%)$ \\
\hline
\end{tabular}

Table 3. Comparison between the different subject groups regarding initial PCT levels $(\mathrm{ng} / \mathrm{ml})$.

\begin{tabular}{ccccc}
\hline & \multicolumn{4}{c}{ PCT $(\mathrm{ng} / \mathrm{ml})$} \\
\cline { 2 - 5 } Groups ( No) & Minimum & Maximum & Mean \pm SD & $p$ value \\
\hline $\begin{array}{c}\text { 1. VAP patients } \\
(\text { No }=42)\end{array}$ & 0.65 & 2.82 & $1.546 \pm 0.509$ & $\begin{array}{c}1 \text { vs } 2< \\
0.001\end{array}$ \\
$\begin{array}{c}\text { 2. Non VAP } \\
\text { patient (No=20) }\end{array}$ & 0.01 & 0.12 & $0.061 \pm 0.036$ & $\begin{array}{c}1 \text { vs } 3< \\
0.001\end{array}$ \\
$\begin{array}{c}\text { 3. Healthy control } \\
\text { subjects (No=20) }\end{array}$ & 0.01 & 0.09 & $0.0438 \pm 0.027$ & $\begin{array}{c}2 \text { vs } 3> \\
0.05\end{array}$ \\
\hline
\end{tabular}

Table 4. Comparison of some measurements between the survivor and died groups among VAP patients.

\begin{tabular}{cccccc}
\hline Outcome & APACHEII & SOFA & CPIS & $\begin{array}{c}\text { PCT 1 } \\
(\mathrm{ng} / \mathrm{ml})\end{array}$ & $\begin{array}{c}\text { PCT 5 } \\
(\mathrm{ng} / \mathrm{ml})\end{array}$ \\
\hline $\begin{array}{c}\text { Survivors } \\
(\mathrm{No}=22)\end{array}$ & $22.31 \pm$ & $6.40 \pm$ & $7.68 \pm$ & $1.198 \pm$ & $0.81 \pm$ \\
$(\mathrm{Mean} \pm \mathrm{SD})$ & 3.73 & 2.90 & 1.04 & 0.29 & 0.21 \\
$\quad$ Died & & & & & \\
$(\mathrm{No}=20)$ & $26.10 \pm$ & $9.50 \pm$ & $9.25 \pm$ & $1.92 \pm$ & $\begin{array}{c}4.49 \pm \\
(\mathrm{Mean} \pm \mathrm{SD})\end{array}$ \\
4.66 & 1.69 & 2.02 & 0.41 & 0.59 \\
$p$ value & $p<0.01$ & $p<0.001$ & $p<0.01$ & $p<0.001$ & $p<0.001$ \\
\hline
\end{tabular}

tality prediction scores (APACHE II $(\mathrm{R}=0.449)$, CRIP $(\mathrm{R}=0.403)$ and SOFA $(\mathrm{R}=0.437))$ and initial PCT serum levels.

\section{Discussion}

In this study, there was a highly statistically significant difference $(p$ value $<0.001)$ between VAP patients on one side and both non VAP-ICU patients and healthy control subjects on the other side regarding the mean values of PCT $(1.54 \pm 0.5 \mathrm{ng} / \mathrm{ml}$ among VAP patients, $0.06 \pm 0.03 \mathrm{ng} / \mathrm{ml}$ among non VAP patients, $0.04 \pm 0.02$ $\mathrm{ng} / \mathrm{ml}$ among healthy control subjects). These results are in agreement with that of other investigators. Lee JY, et al., [10] found that the PCT level in the patients with pneumonia $(2.06 \pm 0.60 \mathrm{ng} / \mathrm{ml})$ was significantly higher than that in the healthy controls $(0.05 \pm 0.02 \mathrm{ng} / \mathrm{ml})$. In case-control study carried out by Polzen et al., [11] which included 26 patients with pneumonia found higher PCT levels among pneumonia patients with a cut-off of 


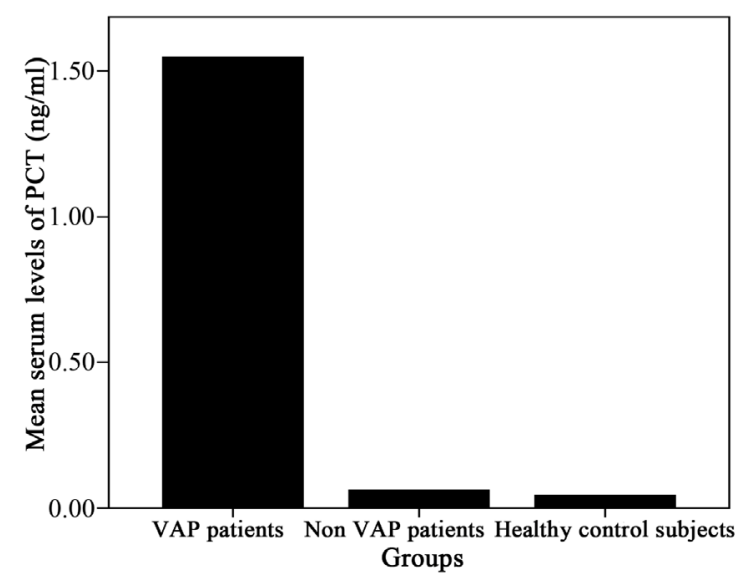

Figure 1. Comparison between the different subject groups regarding initial PCT levels (ng/ml).

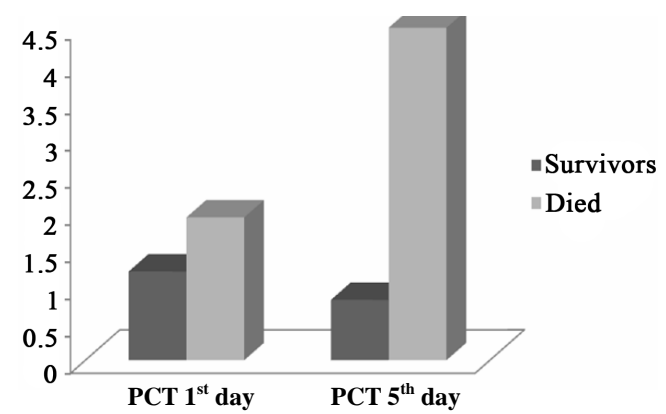

Figure 2. Comparison of the mean PCT levels between the survivor and died groups among VAP patients (first and $5^{\text {th }}$ days respectively).

$0.5 \mathrm{ng} / \mathrm{ml}$. Another study done by Müller and his colleagues [12] with a cohort of 373 subjects demonstrated that PCT with an AUC of $0.85(0.80-0.91)$ was associated with a diagnosis of pneumonia and that PCT improved the ability of clinical findings to diagnose pneumonia $(p<0.001)$. This study postulated that a PCT $<$ $0.1 \mathrm{ng} / \mathrm{ml}$ indicates another diagnosis than pneumonia even with an infiltrate on X-ray. Bafadhel et al. [13] conducted a cohort trial with 319 patients of whom 96 had pneumonia. Patients with pneumonia had a higher PCT $(p<0.0001)$ than those with acute exacerbation of chronic obstructive pulmonary disease (AECOPD). At a cut-off of $0.08 \mathrm{ng} / \mathrm{ml}$, PCT had an AUC of 0.93 (0.88 0.98 ) for differentiation between pneumonia and COPD; sensitivity $89 \%$ (95\% CI 78 - 95) and specificity $78 \%$ (95\% CI 72 - 82). Likewise Seligman and his group [14] found the biomarkers procalcitonin, MR-proANP, and copeptin are increased among VAP patients and can predict mortality in VAP, as can the SOFA score. Procalcitonin alone has the greatest predictive power for such mortality.

There are accumulating data that explain our and other researchers' results. The investigations identified PCT as part of the complex pro-inflammatory response of the innate immune system [15]. In vitro stimulation of macrophages with either bacteria or endotoxin results in rapid synthesis and release of PCT within 4 hours [16]. In a hamster model of Escherichia coli peritonitis, transcription and translation of PCT synthesis was demonstrated in virtually all organs tested and in macrophages [17]. In vitro, endotoxin stimulated adipocytes to synthesize PCT in the absence of macrophages, but synthesis was augmented if adipocytes were incubated with endotoxin-sensitized macrophages [18]. PCT differs from other biomarkers of the invasion by bacterial pathogens by several aspects. Serum PCT serum levels are detectable as early as $3-4 \mathrm{~h}$ after invasion, which is much earlier than the increase in the $\mathrm{C}$-reactive protein level or erythrocyte sedimentation rate [19]. Also, elevated PCT levels have not been noted for other inflammatory conditions, such as acute respiratory distress syndrome, polyarteritis nodosa, systemic lupus erythematosis [8-20]. Available data also indicate that PCT levels are not influenced by therapy with glucocorticoids or nonsteroidal anti-inflammatory agents. PCT levels do not increase in patients with infection due to respiratory viruses [15].

Our study revealed that the mean values of PCT were statistically significantly higher $(p$ value $<0.001)$ among died VAP group than the survivor VAP group on both first day $(1.92 \pm 0.41 \mathrm{ng} / \mathrm{ml}$ vs $1.19 \pm 0.29 \mathrm{ng} / \mathrm{ml}$ respectively) and $5^{\text {th }}$ day measurements $(4.49 \pm 0.59 \mathrm{ng} / \mathrm{ml}$ vs $0.81 \pm$ $0.21 \mathrm{ng} / \mathrm{ml}$ respectively). Other studies found similar results. Duflo et al. [21] found PCT was significantly elevated in non-survivors: the best cut-off for serum PCT in the non-survivors in the VAP group was $2.6 \mathrm{ng} / \mathrm{ml}$ with a sensitivity of $74 \%$ and a specificity of $75 \%$. Likewise, Luyt et al. [22] found high median PCT levels of about $3 \mathrm{ng} / \mathrm{ml}$ at Day 1 in patients with unfavorable outcomes during the clinical course of microbiologically proven VAP $(n=63)$. These results are explained intuitively by that the severe and non respondent pneumonia among the died patients are associated with high bacterial and toxin loads that stimulate excess release of the PCT.

In this study the mean values of PCT increased significantly (from $(1.92 \pm 0.41$ to $4.49 \pm 0.59)$ among died group while decreased significantly (from $1.19 \pm 0.29$ to $0.81 \pm 0.21$ among the survivor group on repeated testing on the $5^{\text {th }}$ day in comparison with the first day measurement. Other studies showed similar results. Harbarth et al., [23] and Jensen and his colleagues [24] found that unsuccessful source control and poor outcome is associated with persistent elevated PCT levels. Also Bloos et al., [25] found that high PCT levels are associated with increased severity of illness in patients with severe pneumonia and appears to be a prognostic marker mortality comparable to the APACHE II score. These results are explained by that the severe and non respondent pneu- 
monia among died patients are associated with sustained high bacterial and toxins load that stimulate a continuous release of the PCT. While survivors are associated with continuous decrease of bacterial and toxin load with less stimulation of PCT release.

Our study found a statistically positive correlation ( $p$ value $<0.01)$ between mortality prediction scores (APACHE II $(\mathrm{R}=0.449)$, CRIP $(\mathrm{R}=0.403)$ and SOFA $(\mathrm{R}=0.437))$ and initial PCT serum levels. Similar observations were reported by Meisner et al., [26] and by Schroder et al., [27] in critically ill patients. Hedlund et al., [28] showed that the severity of disease measured by the APACHE II score was strongly associated with admission levels of PCT in 96 adult patients with CAP. In study included 110 patients with pneumonia, Boussekey et al., [29] found higher PCT levels in bacteremic patients and/or septic shock patients $(4.9 \mathrm{ng} / \mathrm{ml}$ vs 1.5 $\mathrm{ng} / \mathrm{ml}$ ) and in patients who developed infection-related complications (septic shock, multiorgan dysfunction, acute respiratory distress syndrome and disseminated intravascular coagulation) during their ICU stay. Likewise, Bloos et al., [25] found a significant association between PCT levels and organ dysfunction as assessed by the SOFA score. These results suggest that the PCT level can be used as a prognostic factor among VAP patients.

There were some limitations in this study. The number of subjects was small and therefore a study on a larger number of subjects is needed.

\section{Conclusion}

This study found that the increased PCT serum level is an important diagnostic tool for VAP and the PCT serum levels can predict the outcome of VAP patients. We recommend other larger studies to augment our findings.

\section{REFERENCES}

[1] W. G. Melsen, M. M. Rovers and M. J. Bonten, "Ventilator-Associated Pneumonia and Mortality: A Systematic Review of Observational Studies," Critical Care Medicine, Vol. 37, No. 10, 2009, pp. 2709-2718. doi:10.1097/CCM.0b013e3181ab8655

[2] D. Hunter, "Ventilator Associated Pneumonia," British Medical Journal, Vol. 344, No. 7859, 2012, p. e3325. doi:10.1136/bmj.e3325

[3] J. Chastre and J. Y. Fagon, "Ventilator-Associated Pneumonia," American Journal of Respiratory and Critical Care Medicine, Vol. 165, No. 7, 2002, pp. 867-903. doi:10.1164/ajrccm.165.7.2105078

[4] K. L. Dandona Becker, R. Snider and E. S. Nylen, "Procalcitonin in Sepsis and Systemic Inflammation: A Harmful Biomarker and a Therapeutic Target," British Journal of Pharmacology, Vol. 159, No. 2, 2010, pp. 253-264. doi:10.1111/j.1476-5381.2009.00433.x
[5] S. Gibot, M. C. Béné, R. Noel, F. Massin, J. Guy, A. Cravoisy, D. Barraud, M. De Carvalho Bittencourt, J. P. Quenot, P. E. Bollaert, G. Faure and P. E. Charles, "Combination Biomarkers to Diagnose Sepsis in the Critically Ill Patient," American Journal of Respiratory and Critical Care Medicine, Vol. 186, No. 1, 2012, pp. 65-71. doi:10.1164/rccm.201201-00370C

[6] C. Balci, H. Sungurtekin, E. Gürses, U. Sungurtekin and B. Kaptanoglu, "Usefulness of Procalcitonin for Diagnosis of Sepsis in the Intensive Care Unit," Critical Care, Vol. 7, No. 1, 2003, pp. 85-90. doi:10.1186/cc1843

[7] H. K. Wolf, J. K. Gunnewiek, Y. Berk, J. V. D. Ouweland and M. D. Metz, "Comparison of a New Procalcitonin Assay from Roche with the Established Method on the Brahms Kryptor," Clinical Chemistry, Vol. 55, No. 5, 2009, pp. 1043-1044. doi:10.1373/clinchem.2008.117655

[8] A. Alvaro Rea-Neto1, N. C M. Youssef, F. Tuche, F. Brunkhorst, V. M. Ranieri, K. Reinhart and Y. Saker, "Diagnosis of Ventilator-Associated Pneumonia: A Systematic Review of the Literature," Critical Care, Vol. 12, No. 2, 2008, p. R56. doi:10.1186/cc6877

[9] M. Valencia and A. Torres, "Ventilator-Associated Pneumonia," Current Opinion in Critical Care, Vol. 15, No. 1, 2009, pp. 30-35. doi:10.1097/MCC.0b013e3283220e78

[10] J. Y. Lee, S. J. Hwang, J. W. Shim, H. L. Jung, M. S. Park, H. Y. Woo and J. Y. Shim, "Clinical Significance of Serum Procalcitonin in Patients with Community-Acquired Lobar Pneumonia," Korean Journal of Laboratory Medicine, Vol. 30, No. 4, 2010, pp. 406-413.

doi:10.3343/kjlm.2010.30.4.406

[11] A. Polzin, M. Pletz, R. Erbes, M. Raffenberg, H. Mauch, S. Wagner, G. Arndt and H. Lode, "Procalcitonin as a Diagnostic Tool in Lower Respiratory Tract Infections and Tuberculosis," European Respiratory Journal, Vol. 21, No. 6, 2003, pp. 939-943. doi:10.1183/09031936.03.00055103

[12] B. Müller, S. Harbarth, D. Stolz, R. Bingisser, C. Mueller, J. Leuppi, C. Nusbaumer, M. Tamm and M. Christ-Crain, "Diagnostic and Prognostic Accuracy of Clinical and Laboratory Parameters in Community-Acquired Pneumonia," BMC Infectious Diseases, Vol. 7, 2007, pp. 10-20. doi:10.1186/1471-2334-7-10

[13] M. Bafadhel, T. W. Clark, C. Reid, M. J. Medina, S. Batham, M. R. Barer, K. G. Nicholson and C. E. Brightling, "Procalcitonin and C-Reactive Protein in Hospitalized Adult Patients with Community-Acquired Pneumonia or Exacerbation of Asthma or COPD," Chest, Vol. 6, 2011, pp. 1410-1418. doi:10.1378/chest.10-1747

[14] R. Seligman, B. G. Seligman and P. J. Teixeira, "Comparing the Accuracy of Predictors of Mortality in Ventilator-Associated Pneumonia," Jornal Brasileiro de Pneumologia, Vol. 37, No. 4, 2011, pp. 495-503. doi:10.1590/S1806-37132011000400012

[15] P. Schuetz, B. Müller, M. Christ-Crain, D. Stolz, M. Tamm, L. Bouadma, C. E. Luyt, M. Wolff, J. Chastre, F. Tubach, K. B. Kristoffersen, O. Burkhardt, T. Welte, S. Schroeder, V. Nobre, L. Wei, N. Bhatnagar, H. C. Bucher and M. Briel, "Procalcitonin to Initiate or Discontinue Antibiotics in Acute Respiratory Tract Infections," Coch- 
rane Database of Systematic Reviews, Vol. 9, 2012, Article ID: CD007498. doi:10.1002/14651858.CD007498.pub2

[16] D. N. Gilbert, "Procalcitonin as a Biomarker in Respiratory Tract Infection," Clinical Infectious Diseases, Vol. 52, Suppl. 4, 2011, pp. S346-S350. doi:10.1093/cid/cir050

[17] B. Müller, J. C. White, E. S. Nylén, R. H. Snider, K. L. Becker and J. F. Habener, "Ubiquitous Expression of the Calcitonin-I Gene in Multiple Tissues in Response to Sepsis," Journal of Clinical Endocrinology \& Metabolism, Vol. 86, No. 1, 2001, pp. 396-404. doi: $10.1210 /$ jc. 86.1 .396

[18] P. Linscheid, D. Seboek, E. S. Nylen, I. Langer, M. Schlatter, K. L. Becker, U. Keller and B. Müller, "In Vitro and in Vivo Calcitonin I Gene Expression in Parenchymal Cells: A Novel Product of Human Adipose Tissue," Endocrinology, Vol. 144, No. 12, 2003, pp. 55785584. doi:10.1210/en.2003-0854

[19] K. L. Becker, E. S. Nylén, J. C. White, B. Müller and R. H. Snider Jr, "Clinical Review 167: Procalcitonin and the Calcitonin Gene Family of Peptides in Inflammation, Infection, and Sepsis: A Journey from Calcitonin Back to Its Precursors," Journal of Clinical Endocrinology \& Metabolism, Vol. 89, No. 4, 2004, pp. 1512-1525. doi: $10.1210 /$ jc. $2002-021444$

[20] C. A. Scirè, L. Cavagna, C. Perotti, E. Bruschi, R. Caporali and C. Montecucco, "Diagnostic Value of Procalcitonin Measurement in Febrile Patients with Systemic Autoimmune Diseases," Clinical and Experimental Rheumatology, Vol. 24, No. 2, 2006, pp. 123-128.

[21] F. Duflo, R. Debon, G. Monneret, J. Bienvenu, D. Chassard and B. Allaouchiche, "Alveolar and Serum Procalcitonin: Diagnostic and Prognostic Value in Ventilator-Associated Pneumonia," Anesthesiology, Vol. 96, No. 1, 2002, pp. 74-79. doi:10.1097/00000542-200201000-00018

[22] C. E. Luyt, V. Guérin, A. Combes, J. L. Trouillet, S. B. Ayed, M. Bernard, C. Gibert and J. Chastre, "Procalcitonin Kinetics as a Prognostic Marker of Ventilator-Associated Pneumonia," American Journal of Respiratory and Critical Care Medicine, Vol. 171, No. 1, 2005, pp.
48-53. doi:10.1164/rccm.200406-746OC

[23] S. Harbarth, K. Holeckova, C. Froidevaux, D. Pittet, B. Ricou, G. E. Grau, L. Vadas and J. Pugin, "Geneva Sepsis Network Diagnostic Value of Procalcitonin, Interleukin-6, and Interleukin-8 in Critically Ill Patients Admitted with Suspected Sepsis," American Journal of Respiratory and Critical Care Medicine, Vol. 164, No. 3, 2001, pp. 396402. doi:10.1164/ajrccm.164.3.2009052

[24] J. U. Jensen, L. Heslet, T. H. Jensen, K. Espersen, P. Steffensen and M. Tvede, "Procalcitonin Increase in Early Identification of Critically Ill Patients at High Risk of Mortality," Critical Care Medicine, Vol. 34, No. 10, 2006, pp. 2596-2602. doi:10.1097/01.CCM.0000239116.01855.61

[25] F. Bloos, J. C. Marshall, R. P. Dellinger, J. L. Vincent, G. Gutierrez, E. Rivers, R. A. Balk, P. F. Laterre, D. C. Angus, K. Reinhart and F. M. Brunkhorst, "Multinational, Observational Study of Procalcitonin in ICU Patients with Pneumonia Requiring Mechanical Ventilation: A Multicenter Observational Study," Critical Care, Vol. 15, No. 2, 2011, p. R88. doi:10.1186/cc10087

[26] M. Meisner, K. Tschaikowsky, T. Palmaers and J. Schmidt, "Comparison of Procalcitonin (PCT) and C-Reactive Protein (CRP) Plasma Concentrations at Different SOFA Scores during the Course of Sepsis and MODS," Critical Care, Vol. 3, No. 1, 1999, pp. 45-50. doi:10.1186/cc306

[27] J. Schröder, K. H. Staubach, P. Zabel, F. Stüber and B. Kremer, "Procalcitonin as a Marker of Severity in Septic Shock. Langenbecks," Archives of Surgery, Vol. 384, No. 1, 1999, pp. 33-38. doi:10.1007/s004230050170

[28] J. Hedlund and L. O. Hansson, "Procalcitonin and CReactive Protein Levels in Community-Acquired Pneumonia: Correlation with Etiology and Prognosis," Infection, Vol. 28, No. 2, 2000, pp. 68-73. doi: $10.1007 / \mathrm{s} 150100050049$

[29] N. Boussekey, O. Leroy, H. Georges, P. Devos, T. d'Escrivan and B. Guery, "Diagnostic and Prognostic Values of Admission Procalcitonin Levels in CommunityAcquired Pneumonia in an Intensive Care Unit," Infection, Vol. 33, No. 4, 2005, pp. 257-263. doi:10.1007/s15010-005-4096-2 